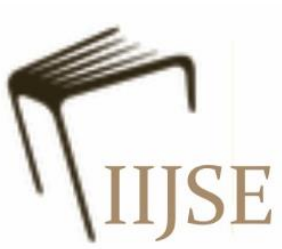

\title{
ANALISIS KINERJA REKSADANA SAHAM SYARIAH DENGAN METODE SHARPE, TREYNOR, JENSEN, ${ }^{2}$, DAN TT
}

\author{
Nur Kholidah $^{1}$, Miftahur Rahman Hakim ${ }^{2}$ \\ Edy Purwanto ${ }^{3}$ \\ STIE Muhammadiyah Pekalongan \\ nur.kholidah92@gmail.com
}

\begin{abstract}
Abstrak
Kata kunci:

Reksa Dana

Saham Syariah,

Sharpe, Treynor,

Jensen, $\mathbf{M}^{2}$ dan

TT

Penelitian ini bertujuan untuk menganalisis kinerja reksadana saham syariah di Indonesia yang diukur menggunakan risiko dan return berdasarkan metode Sharpe, Treynor, Jensen, $\mathrm{M}^{2}$ dan TT periode April - September 2018. Jenis penelitian ini adalah deskriptif kuantitatif. Berdasarkan metode Sharpe dan Treynor menunjukkan hasil yang sama, yaitu tidak terdapat reksadana saham syariah yang berkinerja positif. Selama periode pengamatan (April - September 2018) menggunakan metode Jensen, $\mathbf{M}^{2}$ dan TT hanya ada dua reksadana yang memiliki kinerja terbaik diantara reksadana lainnya karena mampu outperform dari SBIS dan ISSI selama 6 bulan. Reksadana tersebut adalah TRIM Syariah Saham dan Batavia Dana Saham Syariah, oleh karena itu kedua reksadana tersebut adalah reksadana yang layak dijadikan pilihan berinvestasi di tahun 2019 .
\end{abstract}

Keyword:

Financing,

Micro, Small \&

Medium

Enterprises

(MSME),

Profitability
This study aims to analyze the performance of Islamic stock mutual funds in Indonesia that are measured using risk and return based on the Sharpe, Treynor, Jensen, $\mathbf{M}^{2}$ dan TT methods on April - September 2018. This type of research is quantitative descriptive. Based on the Sharpe and Treynor methods show the same results, namely there are no Islamic stock mutual funds that perform positively. During the observation period (April September 2018) using the Jensen, $\mathrm{M}^{2}$ and TT methods there were only two mutual funds that had the best performance among other mutual funds because they were able to outperform the SBIS and ISSI for 6 months. The mutual fund is TRIM Syariah Shares and Batavia Syariah Stock Funds, therefore the two mutual funds are mutual funds that are worth making investment choices in 2019. 


\section{A. Pendahuluan}

Seiring meningkatnya kebutuhan manusia, maka aktivitas ekonomi akan semakin meningkat. Masyarakat modern saat ini mulai merambah dunia investasi dalam rangka memenuhi kebutuhan hidupnya. Menurut Pratomo dan Nugraha dalam Pujiarti dan Dewi (2011:97) ada tiga hal utama yang mendasari investasi yaitu pertama adanya kebutuhan masa depan atau kebutuhan saat ini yang belum mampu untuk dipenuhi saat ini, kedua adanya keinginan untuk menambah nilai aset dan adanya kebutuhan untuk melindungi nilai aset yang sudah dimiliki, ketiga karena adanya inflasi.

Reksa dana merupakan salah satu alternatif investasi bagi masyarakat pemodal, khususnya pemodal kecil yang tidak memiliki banyak keahlian serta waktu untuk menghitung risiko atas investasi mereka, namun memiliki modal dan keinginan untuk melakukan investasi. Berinvestasi di reksa dana akan terkumpul dana yang cukup besar. Adanya dana yang besar di reksa dana dapat dilakukan diversifikasi investasi yang besar sehingga resiko yang dihadapi akan semakin kecil (Hadi, 2013:132). Reksa dana adalah media dan pola pengelolaan dana/modal bagi para investor untuk berinvestasi dalam instrumentinstrumen yang ada di pasar dengan cara membeli unit penyertaan reksa dana. Dana ini lalu dikelola oleh Manajer Investasi (MI) ke dalam portofolio investasi, baik berbentuk saham, obligasi, pasar uang ataupun efek/sekuritas lainnya. Ada beberapa hal yang terkait dari definisi tersebut, yaitu adanya dana dari masyarakat investor, dana investor diinvestasikan dalam portofolio efek, dana investor dikelola oleh manajer investasi. Dengan kata lain, investasi dalam reksa dana merupakan investasi bersama para investor, sedangkan manajer investasi merupakan pihak yang dipercaya untuk mengelola dana tersebut. Seiring perkembangan reksa dana di Indonesia, dewasa ini telah hadir reksa dana Syariah yaitu reksa dana yang khusus menginvestasikan dananya ke dalam sahamsaham perusahaan yang tidak bertentangan dengan prinsip-prinsip Islam. Reksa dana Syariah ini dimaksudkan untuk memberikan alternatif investasi yang lebih luas terutama kepada pemodal muslim. Dengan mayoritas penduduk beragama Islam, Indonesia jelas merupakan pasar potensial bagi tumbuhnya investasi Islami ini.

Dalam Undang-Undang No 8 tahun 1995 Pasal 1 ayat 27 tentang pasar modal, reksa dana didefinisikan sebagai wadah yang dipergunakan untuk menghimpun dana dari masyarakat pemodal untuk selanjutnya diinvestasikan dalam portofolio efek oleh Manajer Investasi (Huda dan Nasution, 
2007:115). Sedangkan menurut MUI, DSN dan BI (2006:115) reksa dana syariah sendiri mengandung pengertian reksa dana yang beroperasi menurut ketentuan dan prinsip syariah Islam, baik dalam bentuk akad antara pemodal sebagai pemilik harta (sahib al-mal) dengan Manajer Investasi sebagai wakil sahib al-mal, maupun antara Manajer Investasi sebagai wakil sahib al-mal dengan pengguna investasi.

Sebagai salah satu instrument investasi, reksa dana syariah memiliki kriteria yang berbeda dengan reksa dana konvensional pada umumnya. Perbedaan ini terletak pada pemilihan instrumen investasi dan mekanisme investasi yang tidak boleh bertentangan dengan prinsip-prinsip syariah. Perbedaan lainnya adalah keseluruhan proses manajemen portofollio, screening (penyaringan), dan cleansing (pembersihan).

Untuk melihat sampai sejauh mana kinerja Reksa Dana yang dimiliki, biasanya para Manajer Investasi melakukan evaluasi kinerja portofolio dengan berbagai metode. Hal itu dilakukan untuk mengetahui bagaimana kinerja portofolio, dalam hal ini reksa dana tersebut berkembang. Penelitian ini juga membandingkan hasil kinerja Reksa Dana saham dengan kinerja benchmark (ISSI) untuk mengetahui Reksa Dana saham yang termasuk outperform maupun underperform. Reksa
Dana saham dinyatakan outperform apabila melebihi kinerja benchmark dan apabila kinerja Reksa Dana saham di bawah kinerja benchmark maka Reksa Dana saham dinyatakan underperform.

Studi-studi di bidang pasar modal telah banyak dilakukan. Di antaranya tentang perbandingan return reksa dana. Dari banyak studi yang telah dilakukan terdapat perbedaan tentang variabelvariabel yang dipilih dan menghasilkan kesimpulan yang berbeda. Nurjanah (2016) melakukan studi dengan judul Analisis Pengukuran Kinerja Reksa Dana Saham Dengan Metode Sharpe, Jensen, Treynor, $\mathbf{M}^{2}$, dan Information Ratio di Bursa Efek Indonesia. Hasil studi ini menunjukkan bahwa selama periode pengamatan (2013-2015) tidak ada Reksa Dana saham yang konsisten berkinerja outperform namun hanya ada dua Reksa Dana yang memiliki kinerja terbaik diantara reksa dana lainnya karena mampu outperform dari BI Rate dan IHSG selama 3 tahun. Selain itu studi yang dilakukan oleh Waridah dan Mediawati (2016) dengan judul Analisis Kinerja Reksa Dana Syariah (2016). Data yang digunakan dalam penelitian ini adalah data sekunder dengan sampel 6 Reksa dana Saham Syariah dengan teknik pengambilan sampel menggunakan purposive sampling. Hasil penelitian menunjukkan bahwa Reksa dana Cipta Syariah Equity 
merupakan Reksa dana Saham Syariah yang memiliki kinerja terbaik dibandingkan dengan Reksa dana Saham Syariah lainnya.

Berbagai penelitian yang berkaitan dengan kinerja reksa dana saham syariah sejauh ini masih jarang yang menggunakan metode MSquare Ratio $\left(\mathrm{M}^{2}\right)$ dan Treynor and Treynor (TT), oleh karena itu pada penelitian ini kinerja reksadana diukur menggunakan metode Metode Sharpe, Jensen, Treynor, $\mathbf{M}^{2}$, dan TT dengan proxy return ISSI yang dijadikan benchmark. Dari data yang dihasilkan dapat dijadikan sebagai pedoman bagi para investor untuk menentukan Reksa Dana saham mana yang akan dimasukkan kedalam portofolionya. Berdasarkan penjelasan latar belakang yang telah disampaikan, maka peneliti tertarik untuk melakukan penelitian dengan judul "Analisis Kinerja Reksa Dana Saham Syariah Dengan Metode Sharpe, Treynor, Jensen, $\mathrm{M}^{2}$ dan TT.

\section{B. Kajian Pustaka}

\section{Investasi dalam perspektif Syariah}

Investasi adalah penanaman modal untuk satu atau lebih aktiva yang dimiliki dan biasanya berjangka waktu lama dengan harapan mendapatkan return dimasa-masa yang akan datang (Sunariyah, 2003:4). Keputusan penanaman modal tersebut dapat dilakukan oleh individu atau suatu entitas yang mempunyai kelebihan dana.
Investasi modal yang sebaik-baiknya menurut Al-Quran adalah tujuan dari semua aktivitas hendaknya diniatkan untuk ibtighai mardhatillah (menuntut keridhaan Allah). Prinsip Islam dalam hal berinvestasi adalah semua hal yang sesuai dengan syariah dan mengacu pada kehalalan serta keadilan bagi semua pihak yang terlibat. Adanya manfaat dari investasi dengan prinsip islam, maka dapat dilakukan bagi hasil atas keuntungan yang diperoleh. Intinya, semua hal yang berbasis syariah harus sesuai dengan yang telah ditentukan oleh Allah SWT dalam AlQuran dan hadist Nabi Muhammad SAW.

Menurut Metwally (dalam Yuliana, 2010:12) seorang muslim boleh memilih tiga alternatif atas dananya, yaitu:

a. Memegang kekayaannya dalam bentuk uang kas (idle cash)

b. Memegang tabungannya dalam bentuk asset tanpa berproduksi seperti deposito bank, pinjaman, real estate, permata

c. Menginvestasikan tabungannya (seperti memiliki proyek-proyek yang menambah persediaan kapital nasional).

\section{Pasar Modal}

Secara umum, pasar modal adalah tempat atau sarana bertemunya antara permintaan dan penawaran atas instrument keuangan (seperti obligasi dan saham) jangka panjang umumnya lebih dari 1 tahun (Samsul, 2006). Pasar modal 
memungkinkan perusahaan memperoleh sumber pembiayaan jangka panjang yang relative murah dari instrumen-instrumen keuangan dalam berbagai surat berharga (sekuritas). Melakukan investasi di pasar modal setidaknya harus memperhatikan dua hal, yaitu: keuntungan yang akan diperoleh dan risiko yang mungkin terjadi.

\section{Reksadana Syariah}

Menurut Fatwa DSN Nomor 20/DSNMUI/IV/2001 "Reksa dana syariah adalah Reksadana yang beroperasi menurut ketentuan dan prinsip-prinsip syariah Islam, baik dalam bentuk akad antara pemodal dengan manajer investasi (wakil pemodal), maupun antara manajer investasi dengan pengguna investasi”. Reksadana syariah merupakan Reksadana yang mengalokasikan seluruh dana atau portofolio ke dalam instrumen syariah, seperti saham yang tergabung dalam Jakarta Islamic Index (JII), obligasi syariah dan berbagai instrumen keuangan syariah lainnya (Sutedi, 2011:8).

Dari sisi peraturan Bapepam, Reksadana Indonesia di bagi dalam empat jenis kategori (Pratomo dan Nugraha, 2009:68-75), yakni:

a. Reksadana Pasar Uang

Reksadana pasar uang didefinisikan sebagai reksadana yang melakukan investasi 100\% pada efek pasar uang.

b. Reksadana Pendapatan Tetap
Reksadana pendapatan tetap adalah reksadana yang melakukan investasi sekurangkurangnya $80 \%$ dari portofolio yang dikelolanya ke dalam efek bersifat hutang.

c. Reksadana Saham

Reksadana saham adalah reksadana yang melakukan investasi sekurang-kurangnya $80 \%$ dari portofolio yang dikelolanya ke dalam efek bersifat ekuitas (saham).

d. Reksadana Campuran

Reksadana campuran dapat melakukan investasinya baik pada efek hutang maupun ekuitas dan porsi alokasi yang lebih fleksibel.

\section{Tolok Ukur (Benchmark) Reksa Dana}

Indeks pasar merupakan indikator kerja untuk suatu jenis instrumen atau portofolio tertentu. Di Indonesia ada beberapa indeks saham yang digunakan untuk mengukur indeks pasar, misalnya IHSG, LQ45, JII, ISSI dan Indeks Sektoral. Penggunaan tolok ukur dalam pengukuran kinerja reksadana dimaksudkan untuk membandingkan apakah kinerja reksadana yang dikelola manajer investasi dapat "mengalahkan" (outperform) pasar atau justru "kalah" (underperform)" dari pasar. Dalam penelitian ini indeks pasar reksa dana syariah yang digunakan adalah Indeks Saham Syariah Indonesia (ISSI).

\section{Evaluasi Kinerja Reksadana}

Evaluasi terhadap kinerja merupakan salah satu hal penting yang harus diperhatikan dalam 
memilih jenis reksadana yang menjadi tujuan investasi. Metode evaluasi kinerja portofolio secara khusus hanya mengukur return dan risiko dari portofolio investasi reksa dana yang bersangkutan. Tandelilin

(2010:489) menjelaskan bahwa dalam mengevaluasi kinerja reksadana harus memperhatikan tingkat return reksadana yang diperoleh harus sudah cukup memadai untuk menutup risiko yang harus ditanggung. Dengan kata lain, evaluasi kinerja reksadana harus didasarkan pada ukuran yang bersifat risk-adjusted. Metode-metode yang digunakan untuk mengevaluasi kinerja portofolio yang bersifat risk-adjusted adalah sebagai berikut:

a. Metode Sharpe

Pengukuran dengan metode Sharpe didasarkan atas apa yang disebut premium atas risiko atau risk premium. Risk premium adalah selisih antara rata-rata kinerja yang dihasilkan oleh reksadana dengan rata-rata kinerja investasi yang bebas risiko (risk free rate).

b. Metode Treynor

Pengukuran dengan metode Treynor juga didasarkan atas risk premium, seperti halnya yang dilakukan Sharpe, namun dalam metode Treynor digunakan pembagi beta (B) yang merupakan risiko berfluktuasi relative terhadap risiko pasar. Beta dalam konsep Capital Asset Pricing Model (CAPM) merupakan risiko sistematik.
c. Metode Jensen

Sama halnya dengan metode Treynor, Jensen menggunakan faktor beta (ß) dalam mengukur kinerja investasi suatu portofolio yang didasarkan atas pengembangan Capital Asset Pricing Model (CAPM). Pengukuran dengan metode Jensen menilai kinerja manajer investasi berdasarkan atas seberapa besar manajer investasi tersebut mampu memberikan kinerja di atas kinerja pasar sesuai risiko yang dimilikinya. Semakin tinggi nilai positif alfa, semakin baik kinerjanya.

d. M-Square Ratio $\left(\mathrm{M}^{2}\right)$

$\mathrm{M}^{2}$ merupakan perluasan dari metode Sharpe dengan mengalikan hasil penghitungan Sharpe dengan standar deviasi pasar. Standar deviasi pasar diperoleh dari ISSI.

e. Indeks Treynor and Treynor (TT)

Indeks TT juga merupakan pengembangan kinerja lainnya (Ti) untuk membuatnya menjadi lebih mudah dipahami.

\section{Metode Penelitian}

\section{Jenis Penelitian}

Penelitian ini termasuk penelitian deskriptif kuantitatif dan pendekatannya menggunakan pendekatan deskriptif. Dalam penelitian ini, jenis data yang digunakan adalah data sekunder yaitu data yang telah dikumpulkan atau diolah pihak lain. Dimana data sekunder berasal dari peristiwa-peristiwa yang sifatnya empiris, yang berupa data NAB/Unit harian 
reksa dana saham dan Sertifikat Bank Indonesia Syariah (SBIS).

Data yang digunakan pada penelitian ini adalah data sekunder dimana metode pengumpulan datanya menggunakan metode dokumentasi dari berbagai literature dan situs internet (www.duniainvestasi.com, www.pusatdata.kontan.co.id dan www.ojk.go.id).

\section{Definisi Operasional dan Pengukuran} Variabel

Variabel yang digunakan dalam penelitian ini antara lain:

\section{a. Rate of Return Reksadana}

Return Reksadana dalam suatu periode dapat dilihat dari data NAB/unit. Return Reksadana tersebut dapat dihitung dengan rumus sebagai berikut:

$$
\mathrm{R}_{\mathrm{D}}=\frac{N A B_{t}-N A B_{t-1}}{N A B_{t-1}}
$$

\section{b. Tingkat Return Bebas Risiko (return risk free rate)}

Return Risk free rate adalah investasi dalam instumen keuangan yang memiliki risiko nol atau paling kecil. Dalam hal ini data yang diguankan yaitu Sertifikat Bank Indonesia Syariah (SBIS) rate. Risk free dapat diketahui dengan cara sebagai berikut:

$$
\overline{R f}=\frac{\sum(R f)}{n}
$$

Keterangan:
$\overline{R f} \quad=$ Rata-rata return risk free bulanan

$\sum(R f)=$ Total return risk free periode $\mathrm{n}$

$\mathrm{n} \quad=$ Jumlah periode $\mathrm{n}$

c. Tingkat Pengembalian Pasar

Sebagai variabel pembanding menggunakan Indeks Saham Syariah Indonesia dengan penghitungan sebagai berikut:

$$
\mathrm{R}_{\mathrm{M}}=\frac{I S S I_{t}-I S S I_{t-1}}{I S S I_{t-1}}
$$

Keterangan:

$\mathrm{R} \mathrm{M} \quad=$ Return pasar saham (ISSI)

ISSI $_{\mathrm{t}}=$ Return pasar saham (ISSI) saat ini

ISSI $\mathrm{t}-1=$ Return pasar saham (ISSI) sebelumnya

\section{d. Standar Deviasi}

Standar deviasi dihasilkan menggunakan program Microsoft excel dengan formula (=STDEV) atau menggunakan rumus sebagai berikut:

$$
\sigma=\sqrt{\frac{\sum(x-\mu)^{2}}{n-1}}
$$

e. Beta (ß)

Beta diukur dengan membagi kovarians antara return pasar dan return Reksa Dana saham dengan varians benchmark. Beta dapat dirumuskan sebagai berikut :

$$
\beta_{p}=\frac{\sigma_{i j}}{\sigma_{m^{2}}}
$$

\section{Subjek Penelitian}

Penelitian ini menggunakan metode purposive sampling dalam pengambilan sampel, yaitu memilih sampel dengan kriteria tertentu 
sehingga sesuai dengan studi yang dirancang. Berdasarkan kriteria pemilihan sampel tersebut, maka didapatkan sampel perusahaan selama periode penelitian yaitu pada tanggal 7 Januari 2013 sampai 30 Desember 2015. sebagai berikut:

Tabel 1 Sampel Data Studi

\begin{tabular}{clc}
\hline No. & \multicolumn{1}{c}{ Nama reksadana } & Tipe reksadana \\
\hline 1. & TRIM Syariah Saham & Saham \\
\hline 2. & Batavia Dana Saham syariah & Saham \\
\hline 3. & PNM Ekuitas Syariah & Saham \\
\hline 4. & CIMB-Principal Islamic Equity Growth Syariah & Saham \\
\hline 5. & Mandiri Investa Atraktif Syariah & Saham \\
\hline 6. & Cipta Syariah Equity & Saham \\
\hline 7. & Manulife Syariah Sektoral Amanah & Saham \\
\hline
\end{tabular}

\section{Teknik Analisis Data}

Teknik analisis data yang digunakan dalam penelitian ini deskriptif kuantitatif. Data diolah sesuai dengan definisi operasional variabel menggunakan bantuan program Microsoft Excel dengan langkah-langkah penghitungan sebagai berikut:

Mengumpulkan data NAB harian masingmasing Reksadana saham serta data pergerakan ISSI dan SBIS selama periode pengukuran. Menghitung return rata-rata masing-masing Reksadana saham dan return rata-rata benchmark yaitu ISSI.

Menghitung risk free dengan menggunakan SBIS. Menghitung risiko, terdapat dua risiko yang dijadikan acuan pada penelitian ini, yaitu standar deviasi $(\sigma)$ dan Beta $(\beta)$.

Melakukan analisis penghitungan dengan Risk-Adjusted Return: a. Metode Sharpe

Metode Sharpe dihitung dengan menggunakan rumus (Pratomo dan Nugraha, 2009:204):

$\mathrm{S}_{\mathrm{RD}}=\frac{{\text { Kiner } j a_{R D}-\text { Kiner } j a_{R F}}_{\sigma}}{\sigma}$

Di mana:

SRD $=$ Nilai Rasio Sharpe

KinerjaRD = Rata-rata kinerja reksa dana subperiode tertentu

KinerjaRF = Rata-rata kinerja investasi bebas risiko subperiode tertentu

$\sigma$ $=$ Standar deviasi reksa dana untuk subperiode tertentu

b. Metode Treynor

Metode Treynor dihitung dengan menggunakan rumus (Pratomo dan Nugraha, 2009:205):

$\mathrm{T}_{\mathrm{RD}}=\frac{{\text { Kiner } j a_{R D}-\text { Kiner }_{\text {in }}}_{R F}}{\beta}$

Di mana:

TRD = Nilai Rasio Treynor

KinerjaRD = Rata-rata kinerja reksa dana subperiode tertentu

KinerjaRF = Rata-rata kinerja investasi bebas risiko subperiode tertentu

$\beta=$ Slope persamaan garis hasil regresi linear.

c. Metode Jensen

Metode Jensen dihitung dengan rumus (Pratomo dan Nugraha, 2009:206):

d. M-Square Ratio $\left(\mathrm{M}^{2}\right)$

Metode MM dapat dibandingkan secara langsung dengan rata-rata Pengembalian portfolio pasar (Rm) dengan tujuan untuk 
mengetahui apakah portofolio berkinerja baik atau buruk.

$\mathrm{MM}=(\mathrm{Srd}-\mathrm{Sm}) \sigma \mathrm{m}$

\section{Keterangan:}

Srd $=$ Sharpe Index reksa dana i pada waktu $\mathrm{t}$

Sm = Sharpe Index pasar

$\sigma \mathrm{m} \quad=$ Standar deviasi pasar

e. Treynor and Treynor (TT)

Indeks TT juga merupakan pengembangan kinerja lainnya (Ti) untuk membuatnya menjadi lebih mudah dipahami.

$T T=T i-(R m-R f)$

Keterangan:

$\mathrm{Ti}=$ Treynor Index reksa dana i pada waktu $\mathrm{t}$

$\mathrm{Rm} \quad=$ Tingkat return pasar portofolio

$\mathrm{Rf} \quad=$ Tingkat return risk free

\section{Hasil Penelitian dan Pembahasan}

\section{Kinerja Reksadana Saham Syariah dengan Metode Sharpe}

Tabel 1. Kinerja Reksadana Saham Syariah Periode April - September 2018

\begin{tabular}{|l|l|l|l|l|l|}
\hline No & $\begin{array}{c}\text { Reksa } \\
\text { dana }\end{array}$ & \multicolumn{1}{|c|}{ Rd } & \multicolumn{1}{|c|}{ Rf } & $\begin{array}{c}\text { Standar } \\
\text { Deviasi }\end{array}$ & Sharpe \\
\hline 1. & TRIM & -0.0001 & 0.0002 & 0.0137 & -0.0197 \\
\hline 2. & Batavia & -0.0001 & 0.0002 & 0.0138 & -0.0196 \\
\hline 3. & PNM & -0.0006 & 0.0002 & 0.0134 & -0.0579 \\
\hline 4. & CIMB & -0.0004 & 0.0016 & 0.0121 & -0.0495 \\
\hline 5. & Mandiri & -0.0002 & 0.0002 & 0.0124 & -0.0320 \\
\hline 6. & $\begin{array}{l}\text { Cipta } \\
\text { Syariah }\end{array}$ & -0.0006 & 0.0002 & 0.0133 & -0.0546 \\
\hline 7. & Manulife & -0.0006 & 0.0002 & 0.0123 & -0.0621 \\
\hline
\end{tabular}

Sumber: olah data (2019)

Pada Tabel 1 dapat disimpulkan bahwa terdapat 7 sampel penelitian reksadana saham syariah yang semuanya menghasilkan kinerja negatif. Hal ini menunjukkan bahwa 7 reksadana saham syariah berdasarkan metode Sharpe kurang layak dijadikan sebagai tempat investasi. Kinerja reksadana saham syariah dengan hasil negatif menunjukkan bahwa return yang dihasilkan lebih rendah dari return investasi bebas risiko. Semakin kecil hasil yang diperoleh maka semakin jelek kinerja suatu reksadana saham syariah karena memberikan return yang kecil atas risiko individual yang ditanggungnya.

\section{Kinerja Reksadana Saham Syariah}

\section{dengan Metode Treynor}

Tabel 2. Kinerja Reksa Dana Saham Syariah

Periode April - September 2018

\begin{tabular}{|l|l|c|c|c|c|}
\hline No & $\begin{array}{c}\text { Reksa } \\
\text { dana }\end{array}$ & Rd & Rf & $\boldsymbol{\beta}$ & Treynor \\
\hline 1. & TRIM & -0.0001 & 0.0002 & 1.1895 & -0.0002 \\
\hline 2. & Batavia & -0.0001 & 0.0002 & 1.2002 & -0.0002 \\
\hline 3. & PNM & -0.0006 & 0.0002 & 1.1652 & -0.0007 \\
\hline 4. & CIMB & -0.0004 & 0.0016 & 1.0557 & -0.0006 \\
\hline 5. & Mandiri & -0.0002 & 0.0002 & 1.0832 & -0.0004 \\
\hline 6. & $\begin{array}{l}\text { Cipta } \\
\text { Syariah }\end{array}$ & -0.0006 & 0.0002 & 1.1632 & -0.0006 \\
\hline 7. & Manulife & -0.0006 & 0.0002 & 1.0738 & -0.0007 \\
\hline
\end{tabular}

Sumber: olah data (2019)

Pada Tabel 2 dapat disimpulkan bahwa 7 reksa dana saham syariah tidak ada yang menghasilkan kinerja yang positif dari 7 sampel penelitian. Hal ini terjadi karena return investasi bebas risiko lebih besar dari return reksa dana saham syariah. Hal ini menunjukkan bahwa 7 reksa dana saham syariah berdasarkan metode treynor kurang layak dijadikan sebagai tempat investasi. 
3. Kinerja Reksadana Saham Syariah dengan Metode Jensen

Tabel 3. Kinerja Reksa Dana Saham Syariah Periode April - September 2018

\begin{tabular}{|l|l|c|c|c|c|}
\hline No & $\begin{array}{c}\text { Reksa } \\
\text { dana }\end{array}$ & Rd & Rf & Rm & Jensen \\
\hline 1. & TRIM & -0.0001 & 0.0002 & -0.0005 & -0.0003 \\
\hline 2. & Batavia & -0.0001 & 0.0002 & -0.0005 & -0.0003 \\
\hline 3. & PNM & -0.0006 & 0.0002 & -0.0005 & -0.0002 \\
\hline 4. & CIMB & -0.0004 & 0.0016 & -0.0005 & -0.0001 \\
\hline 5. & Mandiri & -0.0002 & 0.0002 & -0.0005 & -0.00015 \\
\hline 6. & $\begin{array}{l}\text { Cipta } \\
\text { Syariah }\end{array}$ & -0.0006 & 0.0002 & -0.0005 & -0.0001 \\
\hline 7. & Manulife & -0.0006 & 0.0002 & -0.0005 & -0.0002 \\
\hline
\end{tabular}

Sumber: olah data (2019)

Pada Tabel 3 dapat disimpulkan bahwa terdapat 3 reksadana saham syariah yang menghasilkan kinerja positif dan 4 reksadana saham syariah yang menghasilkan kinerja negatif dari 7 sampel penelitian.

Dari ketiga reksa dana yang menghasilkan kinerja positif, hanya terdapat 2 perusahaan reksadana saham syariah yang layak dijadikan sebagai tempat investasi. Perusahaan yang layak tersebut, hasilnya harus lebih baik (outperform) dibandingkan dengan kinerja pasar (ISSI) dan melebihi return investasi bebas risiko (0.00016).

Hal ini menunjukkan bahwa 2 perusahaan reksadana saham syariah berdasarkan metode Jensen yang layak dijadikan sebagai tempat investasi yaitu TRIM Syariah Saham dan Batavia Dana Saham Syariah.

\section{Kinerja Reksa Dana Saham Syariah dengan Metode $M$-Square Ratio $\left(M^{2}\right)$}

Tabel 4. Kinerja Reksa Dana Saham Syariah Periode April - September 2018

\begin{tabular}{|l|l|c|c|c|c|}
\hline No & $\begin{array}{c}\text { Reksa } \\
\text { dana }\end{array}$ & SRd & Sm & $\mathbf{\Sigma m}$ & $\boldsymbol{M}^{\mathbf{2}}$ \\
\hline 1. & TRIM & -0.01967 & -0.04404 & 0.01148 & 0.00028 \\
\hline 2. & Batavia & -0.01956 & -0.04404 & 0.01148 & 0.00028 \\
\hline 3. & PNM & -0.05787 & -0.04404 & 0.01148 & -0.00016 \\
\hline 4. & CIMB & -0.04953 & -0.04404 & 0.01148 & -6.30094 \\
\hline 5. & Mandiri & -0.03202 & -0.04404 & 0.01148 & 0.00014 \\
\hline 6. & $\begin{array}{l}\text { Cipta } \\
\text { Syariah }\end{array}$ & -0.05456 & -0.04404 & 0.01148 & -0.00012 \\
\hline 7. & Manulife & -0.06208 & -0.04404 & 0.01148 & -0.00021 \\
\hline
\end{tabular}

Sumber: olah data (2019)

Pada Tabel 4 dapat disimpulkan bahwa dari 7 sampel penelitian terdapat 3 reksadana saham syariah yang menghasilkan kinerja positif dan 4 reksa dana saham syariah yang menghasilkan kinerja negatif.

Dari ketiga reksadana yang menghasilkan kinerja positif, hanya terdapat 2 perusahaan reksadana saham syariah yang layak dijadikan sebagai tempat investasi. Perusahaan yang layak tersebut, hasilnya harus lebih baik (outperform) dibandingkan dengan kinerja pasar (ISSI) dan melebihi return investasi bebas risiko (0.00016).

Hal ini menunjukkan bahwa berdasarkan metode $\mathrm{M}^{2}$ maka perusahaan yang layak dijadikan sebagai tempat investasi yaitu TRIM Syariah Saham dan Batavia Dana Saham Syariah. 
5. Kinerja Reksa Dana Saham Syariah dengan Metode Treynor and Treynor (TT)

Tabel 5. Kinerja Reksa Dana Saham Syariah

Periode April - September 2018

\begin{tabular}{|l|l|c|c|c|}
\hline No & $\begin{array}{c}\text { Reksa } \\
\text { dana }\end{array}$ & Ti & Rm-Rf & $\begin{array}{c}\text { Metode } \\
\text { TT }\end{array}$ \\
\hline 1. & TRIM & -0.00023 & -0.00051 & 0.00028 \\
\hline 2. & Batavia & -0.00022 & -0.00050 & 0.00028 \\
\hline 3. & PNM & -0.00066 & -0.00051 & -0.00016 \\
\hline 4. & CIMB & -0.00057 & -0.00051 & -0.00006 \\
\hline 5. & Mandiri & -0.00037 & -0.00051 & 0.00014 \\
\hline 6. & $\begin{array}{l}\text { Cipta } \\
\text { Syariah }\end{array}$ & -0.00063 & -0.00051 & -0.00012 \\
\hline 7. & Manulife & -0.00071 & -0.00051 & -0.00021 \\
\hline
\end{tabular}

Sumber: olah data (2019)

Pada Tabel 5 dapat disimpulkan bahwa terdapat 3 reksadana saham syariah yang menghasilkan kinerja positif dan 4 reksa dana saham syariah yang menghasilkan kinerja negatif.

Dari ketiga reksadana yang menghasilkan kinerja positif, hanya terdapat 2 reksa dana saham syariah yang hasilnya melebihi return investasi bebas risiko (0.00016). Hal ini menunjukkan bahwa berdasarkan metode TT perusahaan yang layak dijadikan sebagai tempat investasi, yaitu TRIM Syariah Saham dan Batavia Dana Saham Syariah.

\section{Kinerja Reksa Dana Saham Syariah} yang Memiliki Kinerja Positif dengan Metode Sharpe, Treynor, Jensen, $M^{2}$ dan

\section{TT}

Berdasarkan perhitungan kinerja reksa dana saham syariah dengan menggunakan metode Jensen, $\mathrm{M}^{2}$, TT, TRIM Syariah Saham dan
Batavia Dana Saham Syariah merupakan reksadana saham syariah yang layak dijadikan sebagai tempat investasi karena hasilnya lebih baik (outperform) dibandingkan dengan kinerja pasar (ISSI) dan melebihi return investasi bebas risiko.

\section{E. Penutup}

Dari hasil analisis, dapat diambil kesimpulan sebagai berikut:

1. Berdasarkan metode sharpe dan treynor pada 7 reksa dana saham syariah periode April-september 2018 kurang layak dijadikan sebagai tempat investasi karena bernilai negatif. Hal ini terjadi karena return investasi bebas risiko lebih besar dari return reksa dana saham syariah.

2. Berdasarkan metode Jensen dan $\mathbf{M}^{2}$ terdapat 3 reksa dana saham syariah yang menghasilkan kinerja positif dan 4 reksa dana saham syariah yang menghasilkan kinerja negatif. Perusahaan yang layak dijadikan sebagai tempat investasi, antara lain: TRIM Syariah Saham, Batavia Dana Saham Syariah dan Mandiri Investa Atraktif Syariah.

3. Berdasarkan metode TT terdapat 2 reksa dana saham syariah yang menghasilkan kinerja positif dan 5 reksadana saham syariah yang menghasilkan kinerja negatif. Perusahaan yang layak dijadikan sebagai 
tempat investasi, yaitu TRIM Syariah Saham dan Batavia Dana Saham Syariah.

4. Reksadana saham syariah yang konsisten memiliki kinerja positif dan layak untuk berinvestasi selama April-September 2018 adalah reksa dana TRIM Syariah Saham dan Batavia Dana Saham Syariah menggunakan metode Jensen, $\mathrm{M}^{2}$ dan TT karena hasilnya lebih baik (outperform) dibandingkan dengan kinerja pasar (ISSI) dan melebihi return investasi bebas risiko

\section{F. Daftar Pustaka}

Hadi, Nor. 2013. Pasar modal: acuan teoritis dan praktis investasi di Instrumen keuangan pasar modal. Yogyakarta: Graha Ilmu.

Huda, N., \& Nasution, M. E. 2007. Investasi pada Pasar Modal Indonesia. Jakarta: Prenada Media Group.

Majelis Ulama Indonesia. Dewan Syariah Nasional, \& Bank Indonesia. 2006. Himpunan fatwa Dewan Syari'ah Nasional (Vol. 1). Kerjasama Dewan Syariah Nasional, Majelis Ulama Indonesia [dan] Bank Indonesia.

Mohamad Samsul. 2006. Pasar Modal Dan Manajemen Portofolio. Jakarta: Erlangga.

Nurjanah, Nita. 2016. Analisis Pengukuran Kinerja Reksa Dana Saham Dengan Metode Sharpe, Jensen, Treynor, $\mathrm{M}^{2}$ Dan Information Ratio Di Bursa Efek Indonesia. Jurnal Manajemen Bisnis Indonesia (JMBI), 5(6), 604-615.

Pratomo, E. P., \& Nugraha, U. 2009. Reksa Dana: Solusi Perencanaan Investasi di Era Modern, edisi revisi ke-2. Jakarta: Gramedia Pustaka Utama.
Pujiarti, T., \& Dewi, F. R. 2011. Analisis Kinerja Reksa Dana Saham Dengan Menggunakan Metode Sharpe Dan Jensen Untuk Periode 2005-2009. Jurnal Manajemen dan Organisasi, 2(2), 97-107.

Sunariyah. 2003. Pengantar Pengetahuan Pasar Modal. Edisi Ketiga. Yogyakarta: UPP-AMP YKPN.

Sutedi, A. 2011. Pasar Modal Syariah: Sarana Investasi Keuangan Berdasarkan Prinsip Syariah. Jakarta: Sinar Grafika.

Tandelilin, Eduardus. 2010. Portofolio dan Investasi teori dan aplikasi. Yogyakarta: Kanisius, 8-9.

Waridah, Winda., \& Mediawati, Elis. 2016. Analisis Kinerja Reksadana Syariah. Jurnal Riset Akuntansi dan Keuangan, 4(2), 1077-1086.

Yuliana, Indah. 2010. Investasi Produk Keuangan Syariah. Malang: UINMALIKI PRESS (Anggota IKAPI).

Regulasi

Fatwa Dewan Syariah Nasional (DSN) Nomor 20/DSN-MUI/IV/2001

Sumber Internet

Dunia Investasi. 2018. Data Harga Saham Bursa Efek Indonesia. http://www.duniainvestasi.com/bei/, diakses pada 11 Desember 2018.

http://pusatdata.kontan.co.id, diakses pada 11 Desember 2018.

https://ojk.go.id/id/kanal/syariah/data-danstatistik/reksa-dana-syariah/Default.aspx, diakses pada 11 Desember 2018

https://www.bi.go.id/id/moneter/operasi/lelan g-sbi/Pages/SBIS-20-APRIL-2018.aspx, diakses pada 11 Desember 2018 